\title{
Norway and Its Obligations under ILO 169-Some Considerations after the Recent Stjernøy Supreme Court Case
}

Øyvind Ravna, Professor, Faculty of Law, UiT - The Arctic University of Norway, Trosmø, Norway; Editor-in-chief, Arctic Review on Law and Politics

The Norwegian Supreme Court recently pronounced its first ruling on a case which started with investigations by the Finnmark Commission. The Stjernøy Case ${ }^{1}$ arises from a title claim to land used as pasture by two groups of Sámi reindeer herders. A contributory reason for the claim was that there are mining activities on the island, from which the landowner is entitled to benefit according to the Norwegian Mineral Act. The Supreme Court ruling raises some fundamental questions, among others: what is the significance of ILO 169 in relation to the Finnmark Act?

\section{Norway's obligations under ILO 169}

The land rights identification process underway in Finnmark, the most central Sámi region in Norway, is the result of more than 30 years of political discussions, tug of war, and struggle for Sámi rights to land and water. After the Bondevik Government presented its bill for a Finnmark Act in 2003, which was met with broad criticism, consultations between the Sami Parliament and the Parliamentary Standing Committee on Justice led to a joint recognition that an investigation of land rights was needed to meet Norway's obligations under ILO 169 concerning Indigenous and Tribal Peoples in Independent Countries (ILO 169). Thirteen years earlier, Norway was the first country in the world to ratify ILO 169.

The Norwegian Parliament consequently decided that the 2005 Norwegian Finnmark Act was to be applied within the limitations of ILO 169. This was not only a ratification but also an incorporation of ILO 169 into the Finnmark Act. Through the Act, Norway has established several institutions to meet ILO obligations. These consist among others of a two-stage procedure with an investigating body called the Finnmark Commission, and a court of law, the Uncultivated Land Tribunal for Finnmark. These two bodies have been given the mandate to investigate land rights and settle land disputes, falling directly under Norway's obligations under ILO 169 art. 14 nos 2 and 3, which read: 
2. Governments shall take steps as necessary to identify the lands, which the peoples concerned traditionally occupy, and to guarantee effective protection of their rights of ownership and possession.

3. Adequate procedures shall be established within the national legal system to resolve land claims by the peoples concerned.

Finally, cases can be brought to the Supreme Court of Norway, and eventually to international monitoring bodies. The Finnmark Estate, which has the mandate to own and govern the land of Finnmark until an investigative body has determined the lawful owner, also falls under the auspices of ILO, which has not been discussed here.

The Finnmark Commission, established in 2008, has, after completing investigations of five areas, not recognised any particular Sámi collectively owned land or usage rights. The Stjernøy ruling, pronounced 28 September 2016, is the first Supreme Court Case to arise from these investigations. Whatever one may think about the outcome, the case is interesting from several perspectives, and not primarily because of its substantial outcome. One particular reason is that this is the first time the Supreme Court of Norway has discussed the significance of ILO 169's incorporation into the Finnmark Act. In addition, the Court elaborates on the significance of the state's former ownership in relation to the position of the current landowner, the Finnmark Estate.

Between the lines, one reads that a claim from descendants of the coastal Sámi population that inhabited the island before it fell under the Norwegian state's domain would have had a better chance of succeeding with a claim. At the same time, the Supreme Court indicates that the recognition of the title under the rules on immemorial usage should not be a low threshold offer.

\section{The significance of previous state ownership in Finnmark}

Discussing the significance of previous state ownership in Finnmark, the Supreme Court stated that the government's former legal and factual activities as land owner and administrator of Finnmark should 'in a general way be included as factors in the assessment of claims for property rights on the basis of immemorial usage' (paragraph 73, my emphasis). This means that government decisions and actions are significant, but hardly to the degree that the Finnmark Commission has assumed in its previous reports. The analogy to general property law means that legal activities, especially if they are carried out as part of exercising public authority, are of little importance when it comes to establishing use and ownership rights for the state.

At the same time, the position of the Supreme Court means that it does not support the legislator's intention, including the Sámi Parliament's, that the State's prior ownership cannot be given weight under the identification and recognition process. This understanding was a central element in the settlement between the Sámi Parliament and the Standing Committee of Justice during the consultations that led up to the Finnmark Act. It was based on a mutual recognition that state 
ownership was built on dubious premises and partly inaccurate history perceptions, which in turn meant that ownership could not be sustained and could not form a basis for FeFo rights and ownership.

\section{The significance of ILO 169 incorporation}

Although Norway has ratified ILO 169, it has not been incorporated into Norwegian law through the 1999 Norwegian Human Rights Act, as have general international human rights conventions such as the ICCPR, ICESCR, UNCRC, CEDAW, and the ECHR, which is a prerequisite for it to be legal enforceable with precedence in the Norwegian dualistic legal system. However, ILO 169 is incorporated into Norwegian law through the Finnmark Act section 3, as the first sentence states that ' $[\mathrm{t}]$ he Act shall apply with the limitations that follow from ILO Convention No. 169 ...' The phrase 'with the limitations' does not mean that it has a limited impact, but that incorporation is limited to cover the Finnmark Act.

The Draft documents use the formulation 'a limited incorporation', which means that 'the law should apply with the limitations imposed by the ILO Convention'. This means according to legislators that:

The ILO Convention takes precedence over the Finnmark Act if it should be shown that the provisions of the Act are in conflict with provisions of the ILO Convention. If, however, one finds on the basis of the ILO Convention, that the Act lacks provisions of certain content, this will be a task for the legislature. The Court should, in other words not to use the ILO Convention to build out the Finnmark Act. It will be easier to foresee the consequences of such a limited incorporation than if one were to give the ILO Convention general precedence over all Norwegian legislation. $^{2}$

It has generally been perceived that the ILO 169 takes precedence in the area of the Finnmark Act, including transactions the Finnmark Act regulates. However, the Supreme Court has a far narrower interpretation of the incorporation and has found that it 'was intended to be limited to the provisions of the Finnmark Act'. The first voting judge, who pronounced the judgement, stated that even if the Finnmark Act governs the procedures to clarify property rights, 'it does not regulate the substantive rules that the rights should be clarified on the basis of' (paragraph 76, highlighted by first voting).

This is probably an appropriate interpretation based on the draft documents. However, it narrows the significance of ILO 169. It implies that ILO 169, including Article 14(1), which states 'the concerned peoples' rights of ownership and possession of the lands which they traditionally occupy, shall be recognized', is not given independent significance as a rule of law in the legal identification process framed in the Finnmark Act.

Although the draft documents are to be understood in this way, there is reason to ask if this is an accurate interpretation assessed in terms of the intention and opinion of the legislators. My reason for asking is that it seems strange if legislators only intended to safeguard the wording of the Finnmark Act from conflicting with ILO 
169, which hardly could have come about due to typos or poor legal craftsmanship. The draft documents, particularly the position of the Sámi Parliament, indicate that incorporation was intended to have a broader scope, protecting Sámi customs, and customary law during the legal identification process in the Sámi area.

With the narrow interpretation of the incorporation of ILO 169, there is a reason to ask if Norway will be able to meet its obligations under the convention. That said, it must be taken into consideration that the Supreme Court emphasises that in applying the property law in relation to the Finnmark Act, Article 14 affects 'the application of law through the so-called presumption principle' (paragraph 77). This principle states that Norwegian law as far as possible shall be interpreted in accordance with international law. Moreover, the Supreme Court highlights the importance of the Selbu and Svartskog cases, ${ }^{3}$ referring again to the draft documents, which state:

... the Sámi use and the Sámi perspective and attitude to ownership position, was emphasized for the decision. In the Selbu Case this was particularly evident in the assessment of nomadic use, and in the Svartskog Case this was reflected in the assessment of good faith and with respect to traditional Sami customary law of the property concept (paragraph 84).

The Supreme Court concludes that Sámi customs and customary law should be given significant weight - considerations we have not seen too much of in the Finnmark Commission investigations thus far. In this regard, one can ask if the Supreme Court's rejection of ILO 169 article 14 as an independent, material rule, will have any great practical significance.

\section{NOTES}

1. The Norwegian Supreme Court, Stjernøy Reindeer Husbandry district and Johan J. Sara et al. versus the Finnmark Estate, 28 September 2016, HR-2016-2030-A.

2. Inst. O. nr. 80 (2004-2005) Innstilling fra justiskomiteen om lov om rettsforhold og forvaltning av grunn og naturressurser i Finnmark (the Finnmark Act), p. 33.

3. NRt 2001 p. 769 et seq and NRt 2001 p. 1229 et seq. 